\title{
Assessment of Major Sources Controlling Groundwater Chemistry in Kombolcha Plain, Eastern Amhara Region, Ethiopia
}

\section{Berihu Abadi Berhe*, Fethangest Woldemariyam Tesema and Gebreslassie Mebrahtu}

School of Earth Sciences, College of Natural and Computational Science, P.O. Box 231, Mekelle University, Mekelle, Ethiopia (*berihu.abadi@mu.edu.et; berhag2000@gmail.com).

\begin{abstract}
The study area, Kombolcha town, forms an important industrial town situated in the Eastern Amhara region, Ethiopia. The geology of the area is mainly composed of basalts, rhyolitic ignimbrites, and Quaternary sediments. Hydrogeochemistry and the source of ions in the groundwater of the study area are poorly understood. Therefore, the current study aims to assess the factors and the different hydrochemical processes significantly controlling groundwater quality, source, and chemistry. For this purpose, a total of eighteen groundwater samples were collected using $250 \mathrm{ml}$ sampling bottles at selected points in the dry season (May 2017) and wet season (November 2017). Gibbs diagram, correlation analysis, scatter plots of ionic molar ratio relations, saturation index values (estimated using PHREEQC Interactive 2.8) were used to decipher the hydrogeochemical process. Gibbs diagram shows that the rock-water interaction process is the predominant, $\mathrm{Na}^{+} / \mathrm{Cl}^{-}$and $\mathrm{Ca}^{2+} / \mathrm{Mg}^{2+}$ molar ratio value of all groundwater samples in both seasons reveals that the groundwater chemistry of the area is controlled by silicate minerals weathering. The strong correlation of $\mathrm{Ca}^{2+}$ with $\mathrm{Mg}^{2+}$ in the dry season, and $\mathrm{Ca}^{2+}$ with $\mathrm{HCO}_{3}{ }^{-}$and $\mathrm{Na}^{+}$with $\mathrm{HCO}_{3}{ }^{-}$in the wet season could also be an indication of silicate weathering and ion exchange processes. The impact of anthropogenic practices on groundwater chemistry is also seen from the strong correlation of $\mathrm{Ca}^{2+}$ with $\mathrm{Cl}^{-}, \mathrm{NO}_{3}{ }^{-}, \mathrm{PO}_{4}{ }^{3-}$, and $\mathrm{F}^{-}, \mathrm{NO}_{2}{ }^{-}$with $\mathrm{K}^{+}, \mathrm{Mg}^{2+}$, and $\mathrm{PO}_{4}{ }^{3-}, \mathrm{PO}_{4}{ }^{3-}$ with $\mathrm{F}^{-}$, and $\mathrm{NO}_{3}{ }^{-}$with $\mathrm{Na}^{+}, \mathrm{Cl}^{-}, \mathrm{HCO}_{3}{ }^{-}$. The negative values of chloro-alkaline indices in both seasons indicate base-exchange reaction where an indirect exchange of $\mathrm{Ca}^{2+}$ and $\mathrm{Mg}^{2+}$ of the water with $\mathrm{Na}^{+}$and $\mathrm{K}^{+}$of the host rock occurs. Saturation indices results for the wet season show that the groundwater is undersaturated with respect to calcite, aragonite, dolomite, gypsum, and anhydrite. In the dry season, however, some of the waters are oversaturated with respect to calcite and aragonite. To sum up, the groundwater quality of the study area is controlled by geological processes and anthropogenic effects.
\end{abstract}

Keywords: Hydrochemistry, Rock-water, Silicate weathering, Ion Exchange, Wet season, Dry season, Kombolcha town.

\section{INTRODUCTION}

Geochemical studies of groundwater are crucial to characterize variations in water chemistry as well as to assess the major sources controlling the water chemistry and aquifer' mineral composition is attributed to groundwater chemistry (Lakshmanan et al., 2003). Geology, degree of chemical weathering of the various rock types, quality of recharge water, and water-rock 
interaction controls the chemistry and quality of groundwater (Domenico, 1972; Biao et al., 2020; Kresic, 2007).

Understanding of hydrogeochemistry is key to determining the origin of the chemical composition of groundwater, the water and rock interaction, and the process of groundwater flow (Zaporozec, 1972) and it could guide sustainable groundwater development (Li et al., 2015). Generally, the chemistry of groundwater is governed by a variety of variables, including climate, soil characteristics, types of lithology, the topography of the area, geological structure, residence time, geochemical processes and of course the human activities on the ground (Rajesh et al., 2002; Das Brijraj and Kaur, 2007; Cloutier et al., 2008; Moral et al., 2008; Gastmans et al., 2010).

Currently, the rapid urbanization, the use of agricultural fertilizers and the growth of industrializations, disposal of industrial and municipal liquid waste have all played a significant role in the pollution of surface water and groundwater and have significantly increased the stress on water quality (Chandra et al., 2015; Verma et al., 2016).

Nowadays, almost in all parts of Ethiopia, the demand for water and consequently abstraction for groundwater is increasing from time to time. Anthropogenic activities have had a significant influence on the ecological environment as a result of fast urbanization. Due to the tremendous discharge of industrial effluents and municipal wastewater into rivers, the effect is more noticeable in the water quality in such areas. Understanding the quality of water used for drinking and irrigation, and its potential adverse effects on human health and plant development is very essential.

Kombolcha town is one of the fast developing and emerging as a leading industrial town in Ethiopia and it is one of the towns selected as industrial zone by the government. The town is one of Ethiopia's towns with comparatively more large-scale manufacturing plants as compared to the size of the town. Steel Product Industry, Flour Factory, Textile Factory, Meat Processing Factory, Brewery Factory and Tannery are the major industries existed in the study area. In this town, the industrial effluents are directly discharged to surface water and toxic organic and inorganic chemicals were taken by crops and vegetables when the surface water is used for irrigation (Mohammed, 2015). More ever, groundwater reserve depletion and well interferences are significantly high in the well-field (Gebremichael, 2011). 
According to Mekonnen and Yihenew (2013), due to the release of wastewater from the town to the river, boron concentration was found to be higher than the allowable irrigation limits at Borkena River and analysis results of vegetables also showed that cabbage accumulated more $\mathrm{Fe}$ at Kombolcha agricultural areas. Furthermore, in the leafy vegetables, high concentrations of $\mathrm{Zn}, \mathrm{Fe}, \mathrm{Mn}, \mathrm{Ni}$, and $\mathrm{Pb}$ were detected. It also was found that the chemical parameters in irrigation water had accumulated and modified the soil characteristics of the farmlands, and higher soil $\mathrm{pH}$ values were found in irrigated farmland soils (Eskinder et al., 2011).

Mostly surface water bodies are vulnerable to contamination and affecting the groundwater resource quality when there is an interconnection between surface water and groundwater. Hence, discharging of untreated industrial and municipal wastes to surface water increase with increasing urbanization (Hamere et al., 2017) and deteriorates and degrades the water quality. The geochemical characteristics of groundwater, hydrochemical evaluation, and the factors governing the quality of groundwater are poorly understood in the Kombolcha town, where the groundwater is the only source for drinking, industrial, and agricultural purposes.

Therefore, the current study is carried out to assess the hydrogeochemical characteristics of the groundwater and to investigate the main source that controlling the groundwater chemistry around Komblcha town area using water samples collected during May 2017 (dry season ) and November 2017 (wet season ).

\section{STUDY AREA}

The study area lies between 571500 and $583800 \mathrm{mE}$ longitude and 1219000 and $1234600 \mathrm{mN}$ latitude in the Eastern part of Amhara region, Ethiopia (Fig 1). It is located about $375 \mathrm{Km}$ north of the state capital, Addis Ababa, along the road to Mekelle and $23 \mathrm{Km}$ southeast of Dessie city. It is situated on the western margin of the Main Ethiopian Rift (MER) valley and covers about $120 \mathrm{Km}^{2}$ area. The MER is located at the northern termination of the East African Rift System (EARS) and extends from the Afar triple junction in the north to the Turkana Rift in the south (Marco et al., 2005) (Fig 1).

The general physiographic map of the study area was prepared from DEM (Fig 1). It is distinguished by marked variations in topography and has a very high rugged topography. The altitude ranges from $1759 \mathrm{~m}$ above sea level in the flat areas where the town of Kombolcha is 
situated, to $2910 \mathrm{~m}$ above sea level at Yegof Mountain. The drainage network in this area is roughly north-south orientations and major streams in this physiographical area include Borkena River and streams of Eyole and Werka (Figs 1 and 2).

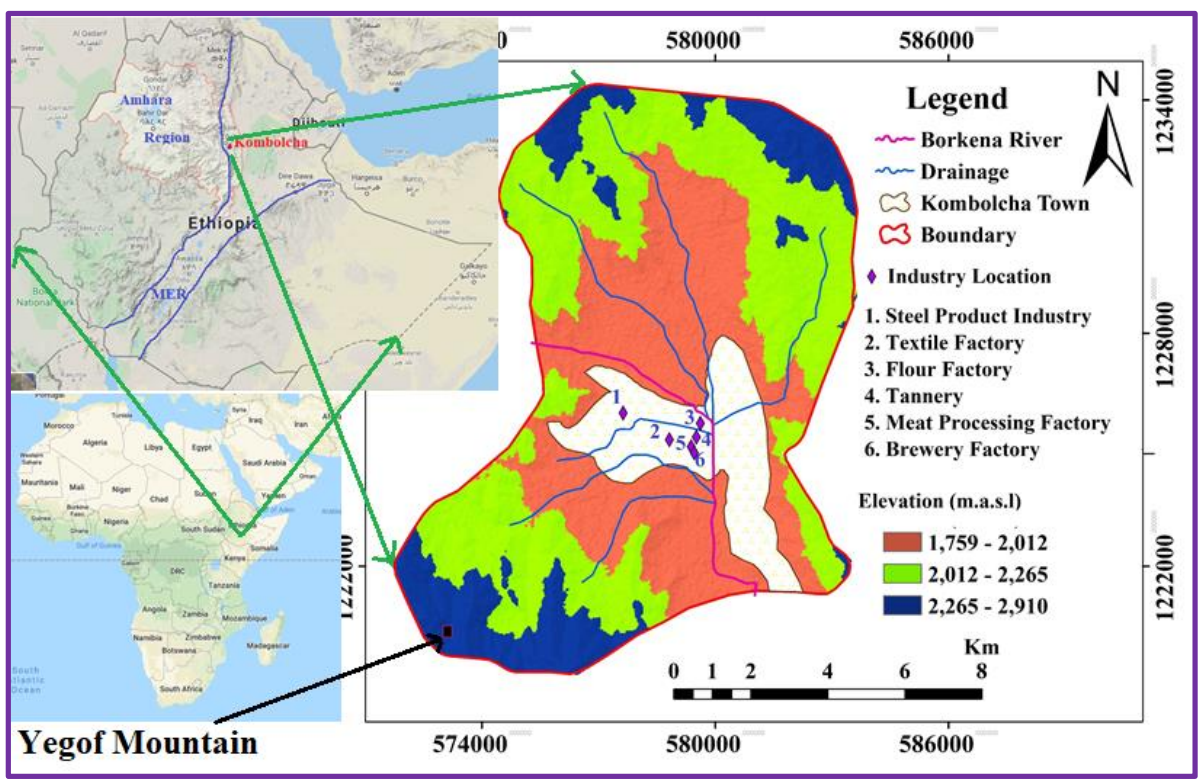

Figure 1. Location map of the study area.

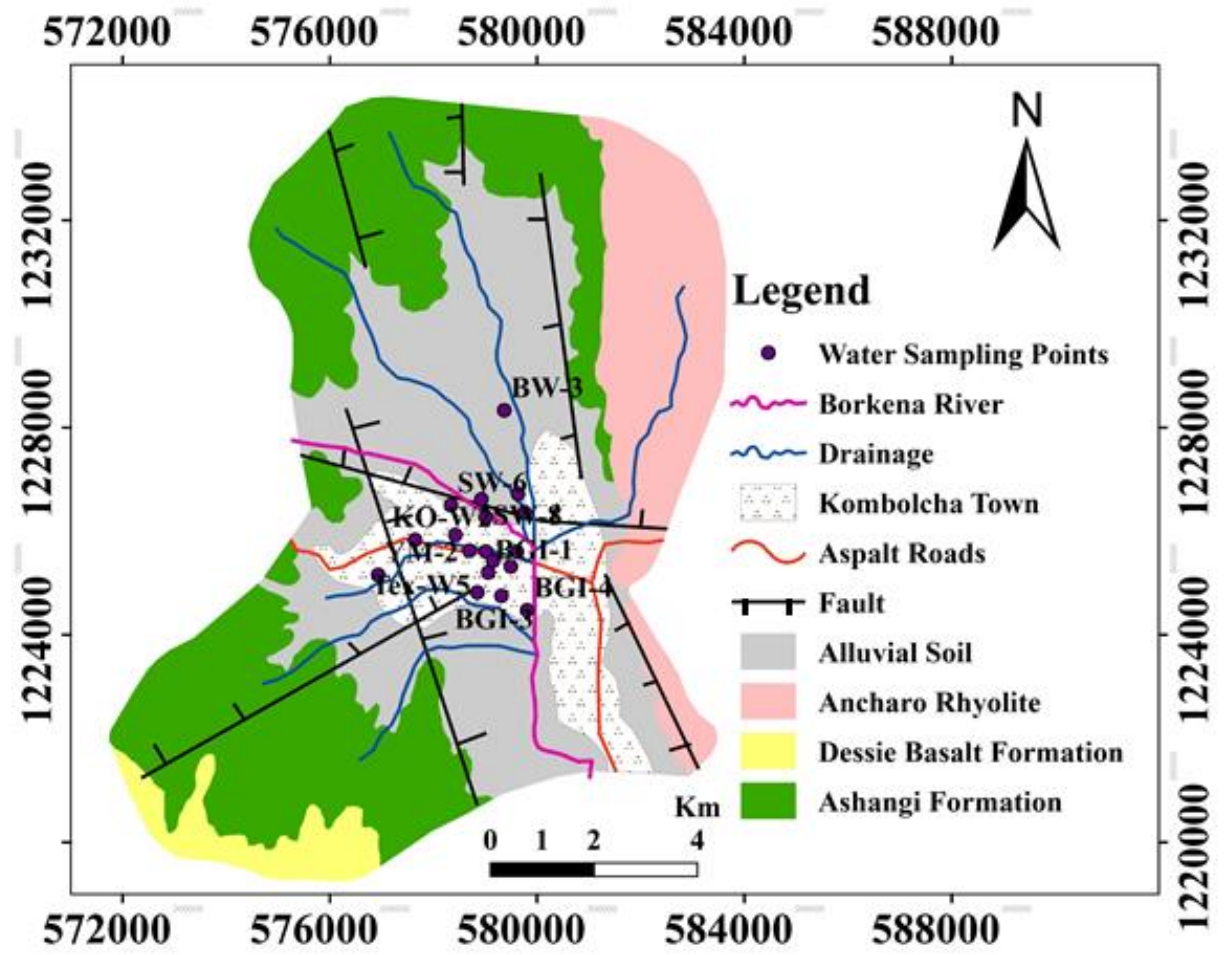

Figure 2. Geological map (Modified after Geological Survey of Ethiopia GSE, (2010) and water sampling point's map of the study area. 
The flat land is covered by human settlements and agricultural areas. Small trees mostly acacia and thorny bushes are common plants in the area and eucalyptus trees are also seen in the ridges in the western part area. The dominant soils in the study area are loam, silty, silty loam, and clay loam and the $\mathrm{pH}$ of the soils ranges between 7.6 and 8 (Mekonnen and Yihenew, 2013). The study area's mean annual rainfall is $1072.15 \mathrm{~mm}$ with the highest rainfall in July and August. The mean annual minimum and maximum temperature of the study area are $12.44^{\circ} \mathrm{C}$ and $26.87^{\circ} \mathrm{C}$, respectively. The mean annual temperature is $19.66^{\circ} \mathrm{C}$. The wet season is lasting from June to September is the while the dry season occurs during the period November to May.

\section{GEOLOGY AND HYDROGEOLOGY}

The geology of the study area is constituted by the rocks ranging in age from Eocene-Oligocene to Recent or Quaternary deposits. Stratigraphically, from oldest to young, they are Ashangie basalts (Eocene-Oligocene), Dessie Basalt Formation and Ancharo Rhyolitic ignimbrite (Oligo-Miocene) and Recent sediments (Quaternary) (Fig 2) (GSE, 2010)).

The Ashangie basalts are also exposed as a faulted block along NW-SE trending escarpment. Its thickness decreases towards the south $(<200 \mathrm{~m})$ along Dessie Kombolcha road (Mengesha et al., 1996; Tesfaye et al., 2010) and it covers about 35.5\% of the study area (Fig 2). The basalts are characterized by strong weathering, different directional tilting, columnar jointing, intense fracturing and crushing. In many of its exposure, it is dominated by inclined columnar jointed aphanitic basalts. It is also characterized by continuous and patchy outcrops with a sheet and blocky forms. The Ashangie basalt is exposed along road cuts, stream beds, gentle and steep slopes of undulating mountain chains and low lying flat plains. The unit is unconformably overlain by Dessie basalt formation. Ashangie basalt is found in N and NW, and SW of the highlands of the study area. The contact with the underlying Ashangie basalt is marked by $50 \mathrm{~cm}$ thick paleosoil from top and bottom as seen along Dessie-Kombolcha road. Its thickness is about $20 \mathrm{~m}$ thick plagioclase phyric basalt (Mengesha et al., 1996; Tesfaye et al., 2010) and it covers about $4 \%$ of the study area. The physical characteristic of this unit is represented by an association of different types of aphanitic and porphyritic, massive and vesicular basalts, with subordinates of pyroclasts and ash layers. Ancharo Rhyolite forms a N$\mathrm{S}$ trending hill in the east part of the study area, which is named after the locality called 
Ancharo. It is well exposed in quarry sites and its thickness is about 50m (GSE, 2010) and covers about $15.5 \%$ of the study area (Fig 2). The rock is white, pink, gray and medium to coarse grained and on the quarry site shows columnar joints. It contains plagioclase, alkali feldspar phenocrysts, glass shards and pumice rock fragments.

The alluvial-colluvial sediments are exposed in the low land plain and cover about 45 $\%$ of the mapped area. They are represented by black cotton and reddish brown silty to sandy soil with few outcrops of diatomite. The black cotton soil is commonly seen along the northern part of the study area. The thickness of the soil is more than $3 \mathrm{~m}$ as observed along the Borkena River cut and stream cuts. The sediments are characterized by clay, sand, gravel, pebbles and boulders derived mainly from the escarpments (Fig 2) and its thickness reaches up to $240 \mathrm{~m}$ as observed from the drilling logs of the boreholes.

Tectonic events that led to the growth of the Rift System control the geological structure of the area. The marginal grabens are slightly elongated depressions bounded on both sides by normal faults facing each other, followed in N-S direction by most of the faults in the study region (Fig 2). The eastern and western ridges bounding the valley area are characterized by a system of opposite dipping faults oriented parallel to the plateau escarpments. The N-S oriented faults show that normal dip-slip movements and form a graben like structure where the town of Kombolcha is situated including the flat low lying area around (Figs 1 and 2).

The main aquifer in the study area is the alluvial sediment. The alluvial deposits show alternating layers of sands, gravel and clay implying that there are multiple layer aquifers. The alluvial sediment is heterogeneous and their porosity and permeability making them a very good aquifer in the study area. The alluvial aquifer, as it was observed from lithological logs, is found at different depths forming a layer in most cases below $30 \mathrm{~m}$ from the ground surface. According to pumping test data available the existing wells in the area showed average yield $10 \mathrm{l} / \mathrm{s}$ and it has good groundwater potential where transmissivity ranges from $88 \mathrm{~m}^{2} /$ day to $335 \mathrm{~m}^{2} /$ day with average transmissivity $210 \mathrm{~m}^{2} /$ day. The volcanic basalts and rhyolites are underlying the alluvial sediments. So far no drilling has been conducted in the volcanic section. All the wells in and around Kombolcha tape from the unconsolidated sediment aquifers. However, the fracture permeability is the most dominant permeability group in the highland areas. The scoriaceous basalt is highly porous due to its abundant vesicles and secondary structures such as joints and fractures interconnection of vesicles (Abraham and Assay, 2011). 


\section{MATERIALS AND METHODS}

Groundwater wells drilled by government, and by private companies and hotels were used to collect groundwater samples. Systematic sampling was carried out in the dry and wet seasons, i.e., during May 2017 and December 2017, respectively. Each season, a total of eighteen (18) groundwater samples were collected.

Sample containers were washed two to three times with the sample solution and rinsed three times with distilled water. Samples were taken after the wells were pumped out for about 5 minutes to remove the stagnant water and collected in polyethylene bottles $(250 \mathrm{ml}$ plastic bottles). The containers were sealed and taken to the laboratory and were stored in a refrigerator without freezing to minimize volatilization and biodegradation until analysis at Mekelle University geochemical laboratory (Clesceri et al., 1998).

Water samples were analyzed in Mekelle University, School of Earth Science, geochemical laboratory for major ions and some minor ion elements. Atomic Absorption Spectrometer $5 \mathrm{Ob}$ Variant was used to analyze the major cations like $\mathrm{Na}^{+}, \mathrm{K}^{+}, \mathrm{Ca}^{2+}$ and $\mathrm{Mg}^{2+}$. UV/ Vis- Spectrophotometer Lambda EZ 201(Double Beam) was used to determine ions like $\mathrm{Cl}^{-}, \mathrm{NO}_{3}{ }^{-}, \mathrm{NO}_{2}{ }^{-}, \mathrm{SO}_{4}{ }^{2-}, \mathrm{PO}_{4}{ }^{3-}, \mathrm{NH}_{4}{ }^{+}$and $\mathrm{F}^{-}$. PH meter 3310 JENWAY, Conductivity meter 4310 JENWAY and Multi meter 3910 were used to analyze $\mathrm{p}^{\mathrm{H}}$, Electrical Conductivity and Total Dissolved Solids, respectively, and Total Hardness of the water samples was determined by EDTA and concentration of $\mathrm{Ca}$ and $\mathrm{Mg}$. Bicarbonate and alkalinity were determined by titration method with indicator of Methyl orange and titrant $0.1 \mathrm{~N} \mathrm{HCl}$ (APHA, 2005).

Reliability of the chemical analyses was calculated through a calculation of electrical neutrality between cations and anions, whereby the ionic balances were within $\pm 5 \%$ (Hem, 1989; Appelo and Postma, 1993; Li et al., 2016) and was calculated using equation 1 (Freeze and Cherry, 1979).

$$
\mathrm{EN}=\frac{\sum \text { Cations }-\sum \text { Anions }}{\sum \text { Cations }+\sum \text { Anions }} \ldots \ldots \ldots \ldots \ldots \ldots \ldots \ldots 1
$$

Correlation between different parameters of water chemistry was done by SPSS software package version 20. The saturation indices (SI) of the major mineral phases in the investigated groundwater samples were calculated using the software package PHREEQC Interactive 2.8. Diagrams like Gibbs diagram, scatter diagrams of different between major ions were used to identify the source water chemistries. 


\section{RESULTS AND DISCUSSION}

The summarized chemical and physical parameters of the laboratory result of the surface water and groundwater for the dry and wet seasons of the study area are presented in appendix 1 and 2 , respectively.

\subsection{Hydrochemistry of Groundwater}

The result and statistical description of the physical (temperature, pH, TDS and EC) and chemical parameters of groundwater are presented in appendix 1 and 2. The $\mathrm{pH}$ values of all waters of the study area elaborate a tendency of basic reaction among the groundwater system.

The mean concentration of calcium in groundwater samples is 75.22 and $70.67 \mathrm{mg} / \mathrm{l}$ in the dry and wet seasons, respectively and for magnesium, the average concentration in groundwater is 6.39 and $9.79 \mathrm{mg} / \mathrm{l}$ in the dry and wet seasons, respectively. Analysis of groundwater samples indicates that the mean values of potassium are $0.81 \mathrm{mg} / \mathrm{l}$ and $0.95 \mathrm{mg} / \mathrm{l}$ in the dry and wet season, respectively. According to Kolahchi and Jalali (2006), the lower potassium concentration in groundwater is owing to its greater resistance to weathering and fixation in the form of clay minerals leading to nutrient loss. The mean sodium concentration in groundwater is $31.9 \mathrm{mg} / \mathrm{l}$ in the dry season and $13.9 \mathrm{mg} / \mathrm{l}$ in the wet season. The high concentration of $\mathrm{Na}^{+}$is recorded in the dry season than in the wet season. This is because $\mathrm{Na}^{+}$ will easily continue to dissolve as long as the groundwater level rises in the wet season.

The average concentration of major anions $\mathrm{HCO}_{3}{ }^{-}, \mathrm{SO}_{4}{ }^{2-}$ and $\mathrm{Cl}^{-}$in groundwater is $175.32 \mathrm{mg} / \mathrm{l}, 92.14 \mathrm{mg} / \mathrm{l}$ and $23.98 \mathrm{mg} / \mathrm{l}$ in dry season, respectively, while in wet season the mean values are $193.17 \mathrm{mg} / \mathrm{l}, 71.61 \mathrm{mg} / \mathrm{l}$ and $10.64 \mathrm{mg} / \mathrm{l}$ in wet season, respectively.

\subsection{Hydrogeochemical Processes}

The relationship of water composition and aquifer lithological characteristics can be established using Gibbs diagram. Three separate fields such as evaporation process, precipitation process and rock-water interaction dominance areas are shown in the Gibbs diagram (Gibbs, 1970).

Gibbs diagram (Gibbs, 1970) represents the ratio of $\left(\mathrm{Na}^{+}+\mathrm{K}^{+}\right) /\left(\mathrm{Na}^{+}+\mathrm{K}^{+}+\mathrm{Ca}^{2+}\right)$ and $\mathrm{Cl}^{-} /\left(\mathrm{Cl}^{-}+\mathrm{HCO}_{3}^{-}\right)$as a function of logarithm of the total dissolved solids (TDS) separately is widely used to assess functional sources of dissolved chemical constituents such as rockweathering, precipitation and evaporation. The major solute acquisition mechanisms controlling the concentration of chemical constituents in the groundwater are natural processes 
such as weathering, ion-exchange, and inputs from atmospheric and anthropogenic sources (Xiao et al., 2012).

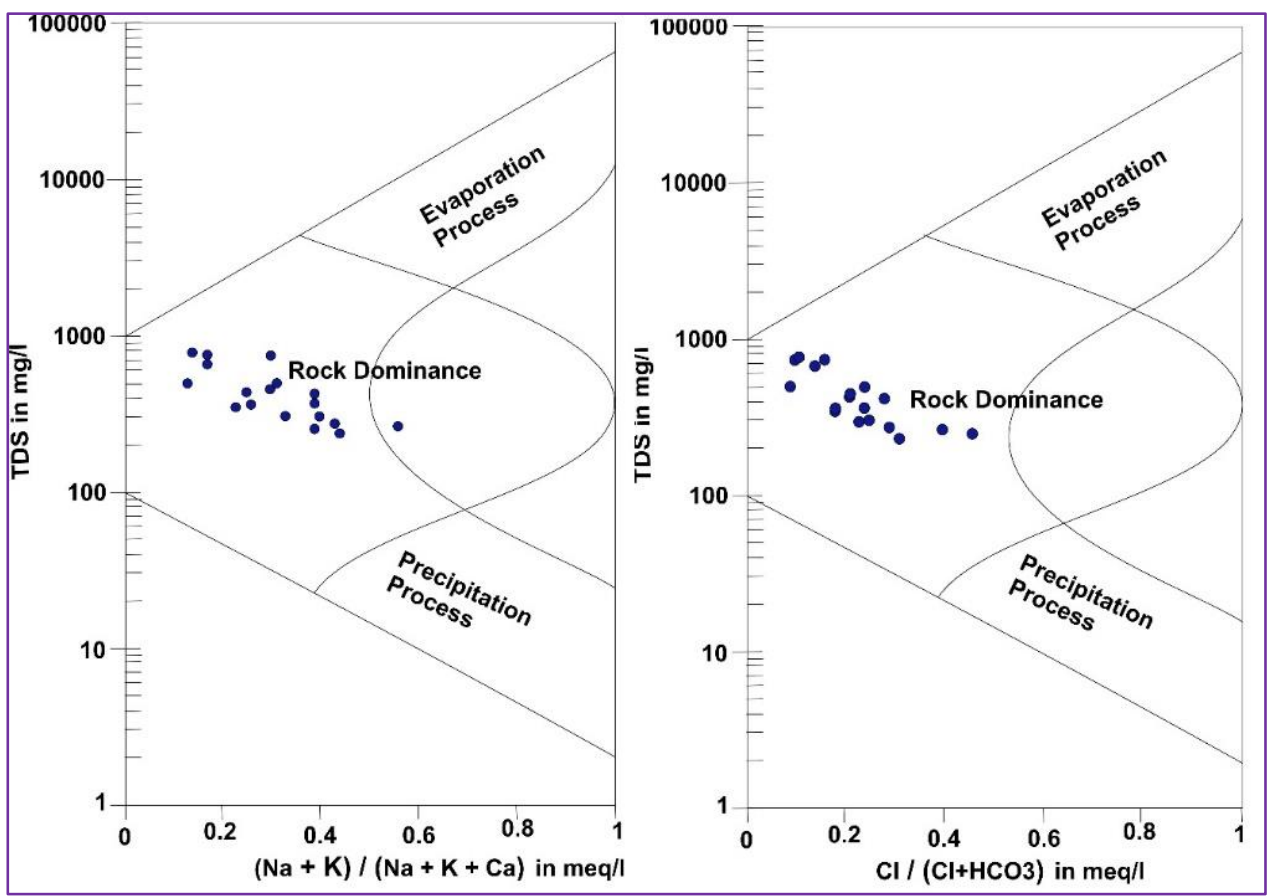

Figure 3. Gibbs diagram of groundwater for May 2017.

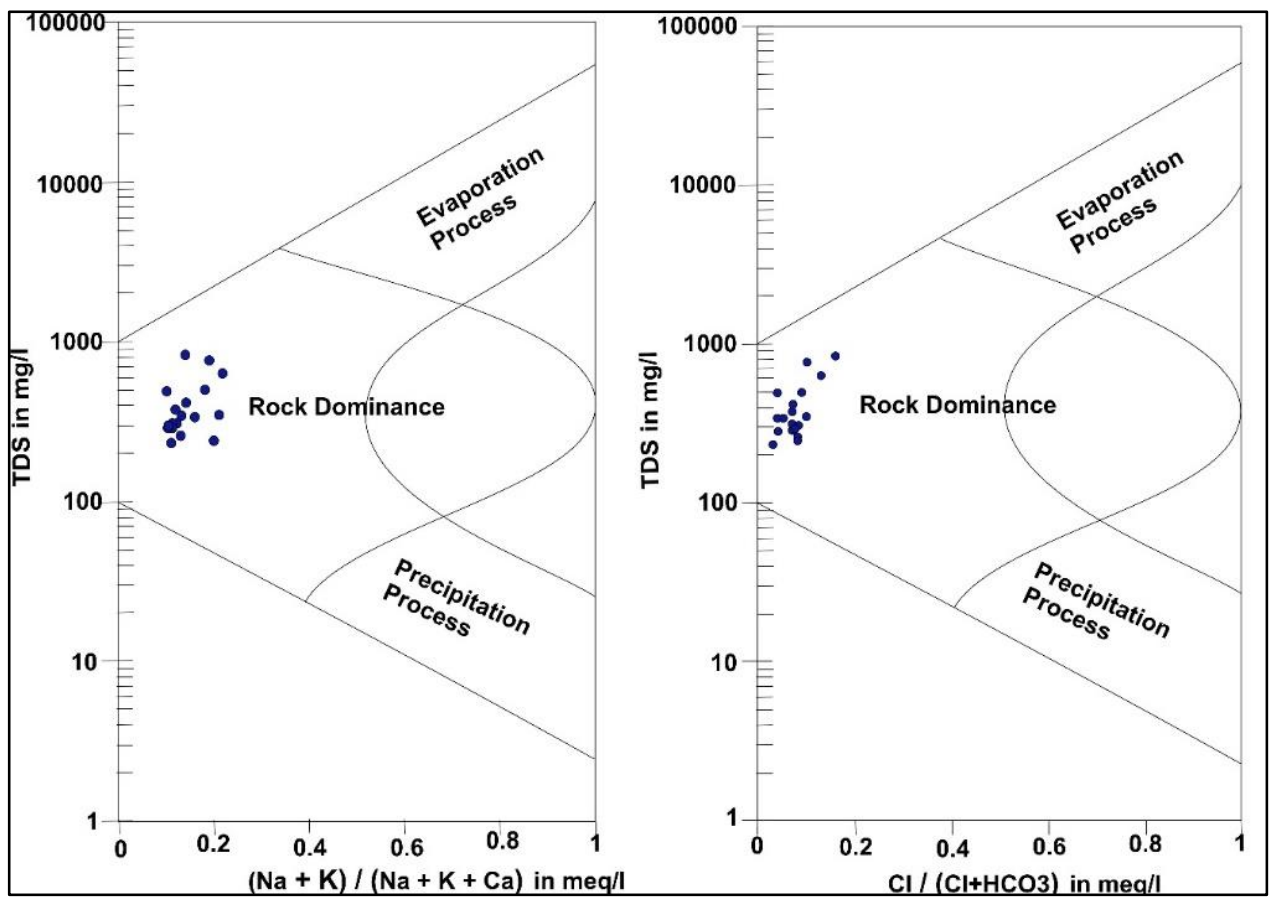

Figure 4. Gibbs diagram of groundwater for November 2017. 
The rock-water interaction dominance field shows the interaction between the rock chemistry and the chemistry of the percolated waters below the subsurface. In the study area. Gibb's diagram (Figs 3 and 4) for groundwater of Kombolcha area displays that the hydrogeochemical processes in all seasons were significantly controlled by weathering (rock dominance) (Kumar et al., 2009). Nevertheless, evaporation and precipitations do not affect water quality.

\subsubsection{Ionic Relations}

Various hydrogeochemical mechanisms involved in the evolution of water chemistry are explained by the relationships between ionic elements using different dispersion diagrams.

\subsubsection{1. $\mathrm{Ca}^{2+} / \mathrm{Mg}^{2+}$ molar ratio}

In natural groundwater, the concentration of $\mathrm{Ca}^{2+}$ and $\mathrm{Mg}^{2+}$ ions result ordinarily from calcite, dolomite and silicate mineral dissolution process. The $\mathrm{Ca}^{2+} / \mathrm{Mg}^{2+}$ molar ratio value shows the type dissolution process dominant during the rock-water interaction. Groundwater's molar ratio of $\mathrm{Ca}^{2+} / \mathrm{Mg}^{2+}$ value 1 point out that the waters are controlled by dolomite dissolution, molar ratio between 1 and 2 is characterized through the calcite dissolution and $\mathrm{Ca}^{2+} / \mathrm{Mg}^{2+}$ ratio $>2$ is primarily owing to the dissolution of silicate minerals, which contribute $\mathrm{Ca}^{2+}$ and $\mathrm{Mg}^{2+}$ in groundwater (Maya and Loucks 1995; Elango et al., 2003). In the current study, all the samples of the two seasons had a ratio $>2$, indicates the effect of silicate minerals (Fig 5).

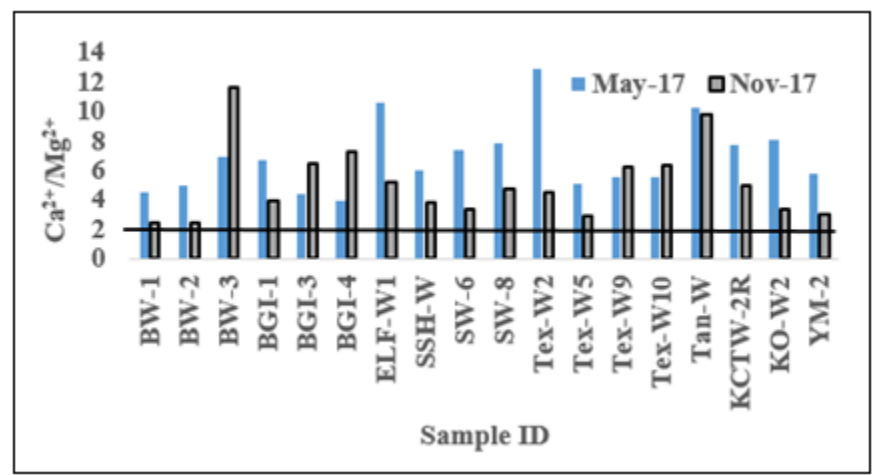

Figure 5. Graph of $\mathrm{Ca}^{2+} / \mathrm{Mg}^{2+}$ molar ratio.

\subsubsection{2. $\mathrm{Na}^{+} / \mathrm{Cl}^{-}$molar ratio}

The calculated value of $\mathrm{Na}^{+} / \mathrm{Cl}^{-}$ratio helps to understand the source of $\mathrm{Na}^{+}$and $\mathrm{Cl}^{-}$in groundwater samples. At natural rock-water interaction process, the halite dissolution is accountable for sodium and the $\mathrm{Na}^{+} / \mathrm{Cl}^{-}$molar ratio is closely one, however, if the ratio is 
greater 1, it is typically assumed that the sodium ion concentration in groundwater samples is released from a silicate weathering reaction (Meybeck, 1987; Prasanna et al., 2019) (Fig 6) The excess $\mathrm{Na}^{+}$in groundwater samples resulted either from silicate weathering reaction or from anthropogenic activities.

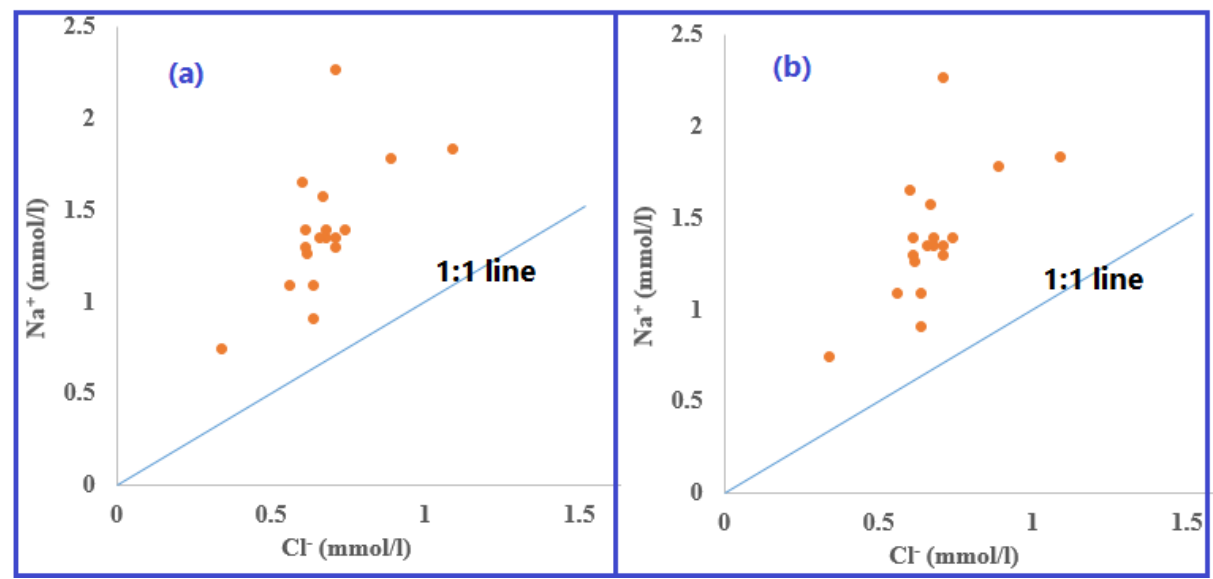

Figure 6. Scatter plots $\mathrm{Na}^{+} / \mathrm{Cl}^{-}$: (a) Dry season, (b) Wet season.

\subsubsection{3. $\left(\mathrm{Ca}^{2+}+\mathrm{Mg}^{2+}\right) /\left(\mathrm{SO}_{4}{ }^{2-}+\mathrm{HCO}_{3}^{-}\right)$molar ratio}

The scatter plot of $\left(\mathrm{Ca}^{2+}+\mathrm{Mg}^{2+}\right)$ concentration against that of $\left(\mathrm{SO}_{4}{ }^{2-}+\mathrm{HCO}_{3}^{-}\right)$is a quantitative indicator of the genesis of ionic concentration in groundwater. Groundwater samples lying close to the 1:1 line indicates the predominance of mineral dissolution, such as that of calcite, dolomite and gypsum (Singh et al. 2011).

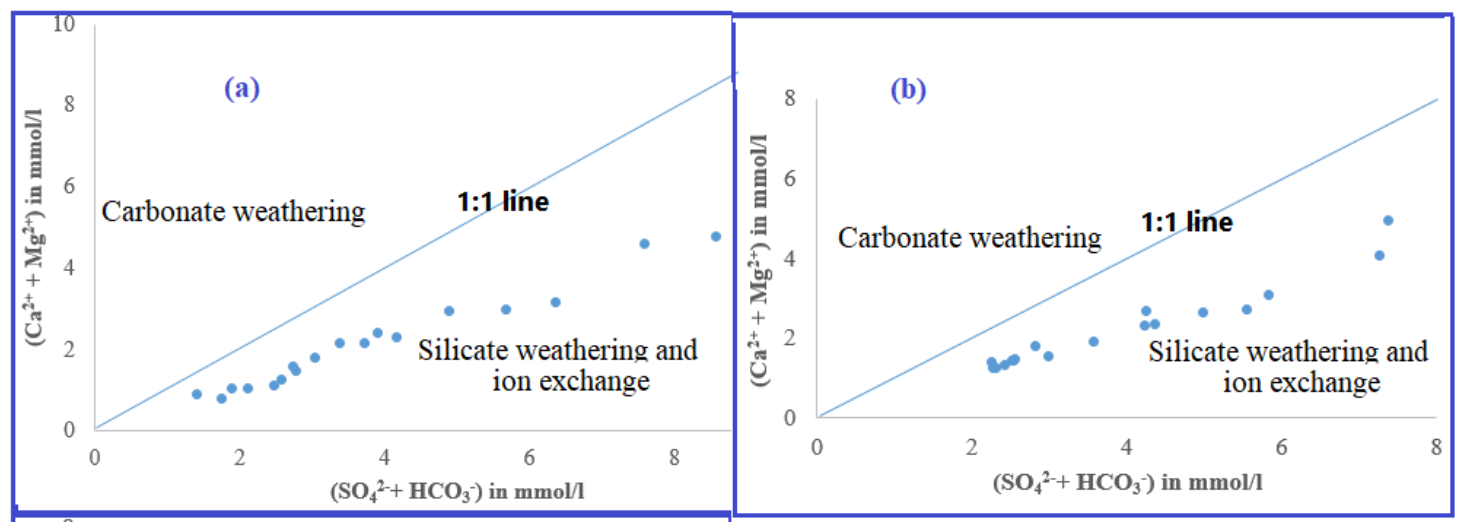

Figure 7. Scatter plots $\left(\mathrm{Ca}^{2+}+\mathrm{Mg}^{2+}\right) \mathrm{Vs}\left(\mathrm{SO}_{4}{ }^{2-}+\mathrm{HCO}_{3}{ }^{-}\right)$: (a) Dry season, (b) Wet season.

The scatter plots $\left(\mathrm{Ca}^{2+}+\mathrm{Mg}^{2+}\right)$ against $\left(\mathrm{SO}_{4}{ }^{2-}+\mathrm{HCO}_{3}{ }^{-}\right)$for groundwater samples of the two separate seasons from the study area are presented in figure 7. According to the plots, 100 
$\%$ of the sample points plot below the equiline $(1: 1)$, which indicates the dominance of silicate weathering and ion exchange in the study area.

\subsubsection{Correlation Analysis}

The computed correlation coefficients are used to prove the degree of correspondence among the different hydrogeochemical parameters of groundwater in the study area. Statistical analysis was executed on the major ion concentration and physio-chemical parameters to detect the relationship and differences between the groundwater samples (Tables 1 and 2).

The correlation analysis results show that EC and TDS values of the samples have a high correlation $(r=0.99)$ with one another in both seasons in Kombolcha area showed that electrical conductivity is a function of TDS (Srivastava and Ramanathan, 2008). A strong correlation $(0.76<\mathrm{r}<0.9) \mathrm{EC}$ with $\mathrm{Ca}^{2+}, \mathrm{Mg}^{2+}, \mathrm{K}^{+}, \mathrm{SO}_{4}{ }^{2-}, \mathrm{HCO}_{3}{ }^{-} \mathrm{NO}_{3}{ }^{-}$and $\mathrm{NO}_{2}{ }^{-}$in dry season (May 2017 ) and also a strong relation $\left(0.72<\mathrm{r}<0.95\right.$ ) with $\mathrm{Ca}^{2+}, \mathrm{Na}^{+}, \mathrm{K}^{+}, \mathrm{NH}_{4}^{+}, \mathrm{Cl}^{-}, \mathrm{SO}_{4}{ }^{2-}$, $\mathrm{HCO}_{3}{ }^{-}, \mathrm{NO}_{3}{ }^{-}$and $\mathrm{PO}_{4}{ }^{3-}$ in wet season (Nov 2017) ( Tables 1 and 2). This implies that EC and TDS of the groundwater samples of the study area are mostly controlled by these ions.

Table 1. Correlation coefficient matrix of major cations and anions (Dry season: May 2017).

\begin{tabular}{|c|c|c|c|c|c|c|c|c|c|c|c|c|c|c|c|c|}
\hline & $p H$ & $C a$ & $M g$ & $K$ & $\mathrm{Na}$ & $\mathrm{NH4}$ & $\mathrm{Cl}$ & $\mathrm{SO4}$ & $\mathrm{HCO3}$ & $\mathrm{CO3}$ & $\mathrm{NO}_{3}$ & $\mathrm{NO}_{2}$ & PO4 & $F-$ & $T D S$ & $\overline{E C}$ \\
\hline pH & 1 & & & & & & & & & & & & & & & \\
\hline$C a$ & -0.62 & 1 & & & & & & & & & & & & & & \\
\hline$M g$ & -0.55 & 0.84 & 1 & & & & & & & & & & & & & \\
\hline$K$ & -0.77 & 0.71 & 0.70 & 1 & & & & & & & & & & & & \\
\hline $\mathrm{Na}$ & -0.11 & 0.24 & 0.00 & 0.21 & 1 & & & & & & & & & & & \\
\hline $\mathrm{NH}_{4}$ & -0.38 & 0.37 & 0.59 & 0.37 & -0.19 & 1 & & & & & & & & & & \\
\hline$C l$ & -0.22 & 0.44 & 0.10 & 0.22 & 0.64 & -0.37 & 1 & & & & & & & & & \\
\hline $\mathrm{SO}_{4}$ & -0.47 & 0.77 & 0.71 & 0.55 & 0.43 & 0.33 & 0.23 & 1 & & & & & & & & \\
\hline $\mathrm{HCO}$ & -0.65 & 0.95 & 0.84 & 0.75 & 0.21 & 0.38 & 0.48 & 0.60 & 1 & & & & & & & \\
\hline $\mathrm{CO}$ & 0.93 & -0.46 & -0.37 & -0.71 & -0.15 & -0.25 & -0.18 & -0.35 & -0.49 & 1 & & & & & & \\
\hline $\mathrm{NO}_{3}$ & 0.33 & -0.14 & -0.27 & -0.40 & 0.26 & -0.26 & 0.37 & -0.25 & -0.12 & 0.30 & 1 & & & & & \\
\hline $\mathrm{NO}_{2}$ & -0.45 & 0.69 & 0.84 & 0.70 & 0.11 & 0.60 & 0.13 & 0.55 & 0.74 & -0.26 & -0.28 & 1 & & & & \\
\hline $\mathrm{PO}_{4}$ & -0.55 & 0.67 & 0.66 & 0.53 & 0.29 & 0.55 & 0.36 & 0.46 & 0.75 & -0.36 & -0.20 & 0.74 & 1 & & & \\
\hline$F$ & -0.07 & 0.47 & 0.48 & 0.41 & 0.51 & 0.25 & 0.31 & 0.52 & 0.49 & 0.05 & -0.22 & 0.54 & 0.49 & 1 & & \\
\hline TDS & -0.65 & 0.86 & 0.89 & 0.77 & 0.32 & 0.55 & 0.31 & 0.76 & 0.87 & -0.46 & -0.26 & 0.90 & 0.83 & 0.61 & 1 & \\
\hline$E C$ & -0.65 & 0.86 & 0.89 & 0.77 & 0.32 & 0.55 & 0.31 & 0.76 & 0.87 & -0.46 & -0.26 & 0.90 & 0.83 & 0.61 & 0.99 & 1 \\
\hline
\end{tabular}


Table 2. Correlation coefficient matrix of major cations and anions (Wet season: Nov, 2017).

\begin{tabular}{|c|c|c|c|c|c|c|c|c|c|c|c|c|c|c|c|c|}
\hline & $p H$ & $\mathrm{Ca}$ & $M g$ & $\boldsymbol{K}$ & $\mathrm{Na}$ & $\mathrm{NH} 4$ & $\mathrm{Cl}$ & $\mathrm{SO4}$ & HCO3 & $\mathrm{CO} 3$ & $\mathrm{NO}_{3}$ & $\mathrm{NO}_{2}$ & PO4 & $F_{-}$ & $T D S$ & $E C$ \\
\hline$p H$ & 1 & & & & & & & & & & & & & & & \\
\hline $\mathrm{Ca}$ & -0.77 & 1 & & & & & & & & & & & & & & \\
\hline$M g$ & -0.27 & 0.50 & 1 & & & & & & & & & & & & & \\
\hline$K$ & -0.36 & 0.58 & 0.63 & 1 & & & & & & & & & & & & \\
\hline $\mathrm{Na}$ & -0.61 & 0.87 & 0.61 & 0.53 & 1 & & & & & & & & & & & \\
\hline $\mathrm{NH} 4$ & -0.67 & 0.71 & 0.72 & 0.62 & 0.73 & 1 & & & & & & & & & & \\
\hline $\mathrm{Cl}$ & -0.72 & 0.92 & 0.45 & 0.55 & 0.93 & 0.66 & 1 & & & & & & & & & \\
\hline $\mathrm{SO}_{4}$ & -0.53 & 0.82 & 0.60 & 0.59 & 0.71 & 0.56 & 0.68 & 1 & & & & & & & & \\
\hline $\mathrm{HCO}_{3}$ & -0.72 & 0.91 & 0.65 & 0.62 & 0.90 & 0.88 & 0.86 & 0.67 & 1 & & & & & & & \\
\hline $\mathrm{CO}_{3}$ & -0.37 & 0.42 & 0.59 & 0.37 & 0.40 & 0.62 & 0.40 & 0.35 & 0.51 & 1 & & & & & & \\
\hline $\mathrm{NO}_{3}$ & -0.69 & 0.93 & 0.54 & 0.54 & 0.94 & 0.67 & 0.97 & 0.72 & 0.89 & 0.41 & 1 & & & & & \\
\hline $\mathrm{NO}_{2}$ & -0.24 & 0.47 & 0.67 & 0.82 & 0.57 & 0.64 & 0.57 & 0.43 & 0.60 & 0.46 & \begin{tabular}{|l}
0.57 \\
\end{tabular} & 1 & & & & \\
\hline $\mathrm{PO}_{4}$ & -0.65 & 0.83 & 0.12 & 0.39 & 0.58 & 0.29 & 0.78 & 0.70 & 0.56 & 0.28 & 0.76 & 0.25 & 1 & & & \\
\hline$F-$ & -0.65 & 0.80 & 0.13 & 0.36 & 0.56 & 0.25 & 0.77 & 0.65 & 0.53 & 0.29 & 0.75 & 0.23 & \begin{tabular}{|l|}
0.99 \\
\end{tabular} & 1 & & \\
\hline$T D S$ & -0.73 & 0.95 & 0.59 & 0.72 & 0.91 & 0.81 & 0.93 & 0.79 & 0.94 & 0.46 & \begin{tabular}{|l|l}
0.92 \\
\end{tabular} & 0.64 & 0.71 & 0.68 & 1 & \\
\hline$E C$ & -0.72 & 0.96 & 0.58 & 0.71 & 0.90 & 0.79 & 0.94 & 0.80 & 0.93 & 0.45 & 0.93 & 0.64 & $\begin{array}{l}0.74 \\
\end{array}$ & 0.70 & 0.99 & 1 \\
\hline
\end{tabular}

The strong correlation $\mathrm{Ca}^{2+}$ and $\mathrm{Mg}^{2+}$ in the dry season and $\mathrm{Ca}^{2+}$ and $\mathrm{Na}^{+}$in the wet season with $\mathrm{HCO}_{3}{ }^{-}$could be an indication of silicate weathering and ion exchange processes. A strong correlation disclosed between $\mathrm{Ca}^{2+}-\mathrm{SO}_{4}{ }^{2-}$ and $\mathrm{Na}^{+}-\mathrm{Cl}^{-}$and (Tables 1 and 2) designates that these ions evolve simultaneously and having probably the same origins and indicating anthropogenic input in groundwater (Srivastava and Ramanathan, 2008).

The correlation of $\mathrm{Ca}^{2+}$ with $\mathrm{Cl}^{-}, \mathrm{NO}_{3}{ }^{-}, \mathrm{PO}_{4}{ }^{3-}$ and $\mathrm{F}^{-}$is very strong and ranges from 0.8 to $0.93, \mathrm{NO}_{2}^{-}$with $\mathrm{K}^{+}, \mathrm{Mg}^{2+}$ and $\mathrm{PO}_{4}{ }^{3-}$ ranges from 0.74 to $0.84, \mathrm{PO}_{4}{ }^{3-}$ with $\mathrm{F}^{-}(\mathrm{r}=0.99)$, and $\mathrm{NO}_{3}{ }^{-}$with $\mathrm{Na}^{+}, \mathrm{Cl}^{-}, \mathrm{HCO}_{3}{ }^{-}$ranges from 0.89 to 0.97 and is very high (Tables 3 and 4). This could result from the poor sanitation municipal and industrial liquid wastes, and agricultural activities like fertilizer, pesticides and herbicides.

\subsubsection{Ion Exchange}

Ion exchange is accountable for the concentration of ions in groundwater. Schoeller (1967) recommended two chloro - alkaline indices (CAI) to indicate the exchange of ions between groundwater and its host rocks during traveling in the aquifer materials. These indices are:

$$
\mathrm{CAI}_{1}=\left[\frac{\left(\mathrm{Cl}^{-}-\left(\mathrm{Na}^{+}+\mathrm{K}^{+}\right)\right.}{\mathrm{Cl}^{-}}\right] \ldots \ldots \ldots \ldots \ldots \ldots \ldots . . \ldots \ldots
$$




$$
\mathrm{CAI}_{2}=\left[\frac{\left(\mathrm{Cl}^{-}-\left(\mathrm{Na}^{+}+\mathrm{K}^{+}\right)\right.}{\mathrm{SO}_{4}^{2-}+\mathrm{HCO}_{3}^{-}+\mathrm{CO}_{3}^{-}+\mathrm{NO}_{3}^{-}}\right] \ldots \ldots \ldots \ldots \ldots \ldots \ldots . \ldots \ldots
$$

According to Nagaraju et al. (2006), negative CAI when there is an exchange of $\mathrm{Ca}^{2+}$ and $\mathrm{Mg}^{2+}$ of the water with $\mathrm{Na}^{+}$and $\mathrm{K}^{+}$of the rocks and is positive CAI indicates the exchange of $\mathrm{Na}^{+}$and $\mathrm{K}^{+}$from the water with $\mathrm{Ca}^{2+}$ and $\mathrm{Mg}^{2+}$ of the rocks.

In both seasons, $100 \%$ of the groundwater samples from the study area disclosed negative values representing an indirect exchange of $\mathrm{Ca}^{2+}$ and $\mathrm{Mg}^{2+}$ of the water with $\mathrm{Na}^{+}$and $\mathrm{K}^{+}$of the host rock (Table 3 ).

Table 3. Chloro Alkaline Indices (CAI, meq/l) and Saturation Indices (SI) of groundwater samples of the two seasons (Dry season: May 2017 and Wet season: Nov 2017).

\begin{tabular}{|c|c|c|c|c|c|c|c|c|c|c|c|c|c|c|}
\hline \multirow{2}{*}{ 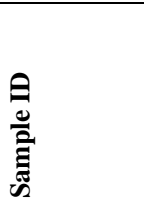 } & \multicolumn{2}{|c|}{ CIA-I } & \multicolumn{2}{|c|}{ CIA-II } & \multicolumn{2}{|c|}{$\begin{array}{l}\text { SI } \\
\text { calcite }\end{array}$} & \multicolumn{2}{|c|}{$\begin{array}{l}\text { SI } \\
\text { aragonite }\end{array}$} & \multicolumn{2}{|c|}{$\begin{array}{l}\text { SI } \\
\text { dolomite }\end{array}$} & \multicolumn{2}{|c|}{$\begin{array}{l}\text { SI } \\
\text { gypsum }\end{array}$} & \multicolumn{2}{|c|}{$\begin{array}{l}\text { SI } \\
\text { anhydrite }\end{array}$} \\
\hline & $\frac{1}{\sum^{3}}$ & $\frac{n}{z}$ & $\frac{\pi}{2}$ & $\frac{n}{2}$ & $\frac{N}{\dot{z}}$ & $\frac{n}{2}$ & $\frac{7}{3}$ & $\frac{n}{2}$ & $\frac{N}{\sum^{3}}$ & $\frac{1}{2}$ & $\frac{N}{2}$ & $\frac{n}{3}$ & $\frac{N}{\sum^{\prime}}$ & $\frac{n}{2}$ \\
\hline BW-1 & -1.17 & -3.98 & -0.16 & -0.11 & 0.31 & -0.89 & 17 & -1.03 & -0.06 & -2.29 & -0.16 & -1.56 & -1.86 & -1.79 \\
\hline BW-2 & -1.36 & -1.21 & -0.22 & -0.06 & 0.27 & -0.37 & 0.13 & -0.51 & -0.18 & -1.28 & -1.70 & -1.76 & -1.93 & -1.99 \\
\hline BW-3 & -1.23 & -1.93 & -0.07 & -0.06 & -0.22 & -1.01 & -0.37 & -1.15 & -1.41 & -3.27 & -1.34 & -1.55 & -1.56 & -1.78 \\
\hline BGI-1 & -1.01 & -0.72 & -0.18 & -0.03 & 0.23 & -1.17 & 0.09 & -1.31 & -0.38 & -2.98 & -1.82 & -2.00 & -2.02 & -2.21 \\
\hline BGI-3 & -0.43 & -1.77 & -0.12 & -0.06 & 0.21 & -0.99 & 0.07 & -1.13 & -0.14 & -2.87 & -2.06 & -1.94 & -2.27 & -2.16 \\
\hline BGI-4 & -1.80 & -1.25 & -0.38 & -0.08 & 0.15 & -1.54 & 0.01 & -1.69 & -0.23 & -4.00 & -2.02 & -2.10 & -2.23 & -2.31 \\
\hline ELF-W1 & -0.70 & -0.96 & -0.07 & -0.10 & 0.12 & -0.86 & -0.02 & -1.00 & -1.03 & -2.63 & -1.14 & -1.50 & -1.36 & -1.73 \\
\hline SSH-W & -0.73 & -0.62 & -0.06 & -0.03 & -0.04 & -1.23 & -0.18 & -1.37 & -1.07 & -3.10 & -1.59 & -2.00 & -1.81 & -2.23 \\
\hline SW-6 & -1.08 & -0.96 & -0.13 & -0.05 & -0.09 & -1.21 & -0.23 & -1.35 & -1.10 & -3.01 & -1.42 & -2.00 & -1.63 & -2.22 \\
\hline SW-8 & -1.05 & -1.35 & -0.15 & -0.11 & 0.34 & -0.92 & 0.19 & -1.06 & -0.33 & -2.63 & -1.74 & -1.90 & -1.96 & -2.12 \\
\hline Tex-W2 & -1.03 & -1.14 & -0.18 & -0.08 & -0.87 & -0.93 & -1.01 & -1.07 & -2.96 & -2.70 & -1.62 & -1.72 & -1.82 & -1.94 \\
\hline Tex-W5 & -0.87 & -3.21 & -0.20 & -0.07 & 0.01 & -1.40 & -0.13 & -1.55 & -0.75 & -3.28 & -2.23 & -1.63 & -2.44 & -1.85 \\
\hline Tex-W9 & -1.30 & -3.08 & -0.29 & -0.07 & 0.24 & -1.12 & 0.10 & -1.26 & -0.23 & -3.07 & -2.07 & -2.02 & -2.28 & -2.23 \\
\hline Tex-W10 & -0.93 & -2.35 & -0.24 & -0.13 & 0.27 & -1.28 & 0.13 & -1.42 & -0.17 & -3.40 & -2.27 & -2.00 & -2.44 & -2.21 \\
\hline Tan-W & -0.92 & -0.32 & -0.07 & -0.04 & 0.47 & -0.54 & 0.32 & -0.69 & -0.30 & -2.31 & -1.18 & -1.19 & -1.40 & -1.42 \\
\hline KCTW-2R & -0.97 & -0.66 & -0.12 & -0.04 & 0.27 & -1.28 & 0.13 & -1.43 & -0.42 & -3.32 & -1.69 & -2.05 & -1.90 & -2.27 \\
\hline KO-W2 & -2.21 & -0.83 & -0.20 & -0.04 & 0.03 & -0.96 & -0.11 & -1.10 & -0.95 & -2.59 & -1.24 & -1.76 & -1.45 & -1.98 \\
\hline YM-2 & -1.06 & -1.01 & -0.22 & -0.08 & 0.09 & -0.60 & -0.05 & -0.74 & -0.63 & -1.89 & -2.25 & -1.44 & -2.46 & -1.66 \\
\hline
\end{tabular}

\subsubsection{Saturation Indices (SI) and Chemical Equilibrium}

The saturation indices describe quantitatively the deviation of water from equilibrium with respect to dissolved minerals (Jalali, 2010). The degree of water saturation with respect to a mineral is given by: 


$$
S I=\log \left[K_{I P A} / K_{S P}\right] \ldots \ldots \ldots \ldots \ldots \ldots \ldots . . . \ldots
$$

Where, $\mathrm{SI}$ - is the saturation index

$\mathrm{K}_{\mathrm{IAP}}$ - is the ionic activity product,

$\mathrm{K}_{\mathrm{SP}}$-is the solubility product of the concerned mineral.

The water is at equilibrium or saturated with the mineral phase when SI is equal to zero, SI value < zero (negative value) indicates the water is under-saturated with respect to the given mineral and the mineral phase tends to dissolve, whereas over/supper-saturated and the mineral phase tends to precipitate when the SI value > zero (positive value). The calculated saturation indices for different carbonate and sulphate minerals and presented in table 3.

In the study area, all groundwater samples were under-saturated with respect to carbonate minerals (calcite, aragonite and dolomite) and sulphate minerals (anhydrite and gypsum) in both dry and wet seasons. However, in dry season, $78 \%$ and $55 \%$ of the samples were super-saturated with respect to calcite and aragonite, respectively. In general, the saturated index values of groundwater chemistry of the study area are greater in dry season as compared with the wet season (Table 3). This may be resulted from the less concentration major ions in the wet season due to the greater water levels in the wells during the wet season than in the dry season.

Table 4. Hardness of waters.

\begin{tabular}{|clcc|}
\hline Hardness & Water classification & \multicolumn{2}{c|}{ \% Result of this study } \\
\cline { 3 - 4 } & & May 2017 & Nov 2017 \\
\hline $0-75$ & Soft & 0 & 0 \\
\hline $75-150$ & Moderately hard & 38.9 & 44.4 \\
\hline $150-300$ & Hard & 44.4 & 38.9 \\
\hline$>300$ & Very hard & 16.7 & 16.7 \\
\hline
\end{tabular}

\subsubsection{Hardness}

The concentrations of certain metallic ions, predominantly magnesium and calcium in the water controls the hardness of water. Water hardness usually expressed as total hardness (TH) is given by equation 5 .

$$
\mathrm{TH}=2.5 \mathrm{Ca}^{2+}+4.1 \mathrm{Mg}^{2+} \ldots \ldots \ldots \ldots \ldots \ldots \ldots . .5
$$

Where, TH (Total Hardness), $\mathrm{Ca}^{2+}$ and $\mathrm{Mg}^{2+}$ concentrations are all in mg/l (Todd, 1980). 
The total hardness value ranges from $81 \mathrm{mg} / \mathrm{l}$ to $479 \mathrm{mg} / \mathrm{l}$ and from $116 \mathrm{mg} / \mathrm{l}$ to 521 $\mathrm{mg} / \mathrm{l}$ in May 2017 and November 2017, respectively (Appendix 1 and 2). During the dry season, classification of water based on TH by Freeze and Cherry (1979) (Table 4) indicates that 38.9 $\%$ of the groundwater samples fall into the moderately hard category, $44.4 \%$ hard and $16.7 \%$ fall within the very hard classification. Water analysis from wet season does not show much difference from the dry season (Table 4).

\section{CONCLUSIONS}

The chemical composition of groundwater of the study area is strongly influenced by rock water interaction and weathering of silicates minerals as well as ion exchange processes.

Gibbs diagram disclosed that the rock-water process is the dominant parameter in the area. Scatter plots of $\mathrm{Ca}^{2+/} \mathrm{Mg}^{2+}$, molar ratios of $\mathrm{Na}^{+} / \mathrm{Cl}^{-}$and $\left(\mathrm{Ca}^{2+}+\mathrm{Mg}^{2+}\right) /\left(\mathrm{SO}_{4}{ }^{2-}+\mathrm{HCO}_{3}{ }^{-}\right)$ reveals that weathering of silicates minerals as well as ion exchange processes are the controlling processes of the groundwater chemistry in the study area.

EC and TDS have a high correlation with one another in both seasons. Besides the EC and TDS have a strong correlation with $\mathrm{Ca}^{2+}, \mathrm{Mg}^{2+}, \mathrm{K}^{+}, \mathrm{SO}_{4}{ }^{2-}, \mathrm{HCO}_{3}{ }^{-} \mathrm{NO}_{3}{ }^{-}$and $\mathrm{NO}_{2}{ }^{-}$in dry season and a strong relation with $\mathrm{Ca}^{2+}, \mathrm{Na}^{+}, \mathrm{K}^{+}, \mathrm{NH}_{4}{ }^{+}, \mathrm{Cl}^{-}, \mathrm{SO}_{4}{ }^{2-}, \mathrm{HCO}_{3}{ }^{-}, \mathrm{NO}_{3}{ }^{-}$and $\mathrm{PO}_{4}{ }^{3-}$ in wet season implies that electrical conductivity is a function of TDS. The impact of anthropogenic practices on groundwater chemistry also seen from the strong correlation of $\mathrm{Ca}^{2+}$ with $\mathrm{Cl}^{-}, \mathrm{NO}_{3}{ }^{-}, \mathrm{PO}_{4}{ }^{3-}$ and $\mathrm{F}^{-}, \mathrm{NO}_{2}{ }^{-}$with $\mathrm{K}^{+}, \mathrm{Mg}^{2+}$ and $\mathrm{PO}_{4}{ }^{3-}, \mathrm{PO}_{4}{ }^{3-}$ with $\mathrm{F}^{-}$, and $\mathrm{NO}_{3}{ }^{-}$with $\mathrm{Na}^{+}$, $\mathrm{Cl}^{-}, \mathrm{HCO}_{3}{ }^{-}$.

CAI results indicating that there was an indirect exchange of $\mathrm{Ca}^{2+}$ and $\mathrm{Mg}^{2+}$ of the groundwater with $\mathrm{Na}^{+}$and $\mathrm{K}^{+}$of the host rock. Groundwater of the study area is under-saturated with respect to carbonate minerals (calcite, aragonite, and dolomite) and sulphate minerals (anhydrite and gypsum) in both seasons. In the dry season, however, some of the samples are supper-saturated with respect to calcite and aragonite.

The hardness of the groundwater is almost similar in both wet and dry season. Results shows that most of the Waters fall under moderately hard and hard category and $16.7 \%$ of the waters fall under very hard group. No water was grouped as soft water. Liquid waste treatment problems may be the main source of the anthropogenic effects in the area and the author 
recommended to the administration of the town that all liquid wastes from the industrial should be treated and controlled.

\section{AKNOWLEDGEMENTS}

This work was supported by Wollo University research project (WU/125/2017) and the author is grateful to Wollo University for its valuable financial support. The author is grateful for the critical comments and suggestions of two anonymous reviewers for improving the manuscript.

\section{CONFLICTS OF INTERESTS}

No conflict of interests

\section{REFERENCE}

Abraham, M \& Assay, G. 2011. Groundwater Resource Assessment for Water point selection in Kombolch town (Kombolcha Textile Factory compound and its surroundings). Report, Wollo University (Unpubl.).

APHA, 2005. Standard methods for the examination of water and wastewater. $21^{\text {th }}$ edition, American Public Health Association, Washington D.C.

Appelo, C.A.J \& Postma, D. 1993. Geochemistry, groundwater and pollution. AA Balkema, Rotterdam. ISBN 90-5410-106-7, 536p.

Biao, Z., Dan, Z., Pengpeng, Z., Shen, Q., Fu, L \& Guangcai, W. 2020. Hydrochemical Characteristics of Groundwater and Dominant Water-Rock Interactions in the Delingha Area, Qaidam Basin, Northwest China. Water, 12(3): 836 (https://doi.org/10.3390/w12030836).

Chandra. S., Singh, P.K., Tiwari, A.K., Panigrahy, B.P \& Kumar, A. 2015. Evaluation of hydrogeological factors and their relationship with seasonal water table fluctuation in Dhanbad district, Jharkhand, India. ISH J. Hydraulic Engineering, 21(2): 193-206.

Clesceri, L.C., Greenberg, A.E \& Eaton, A.D. 1998. Standard methods for the Examination of water and waste water. $20^{\text {th }}$ edition. American Health Association: Baltimore (USA).

Cloutier, V., Lefebvre, R., Therrien, R \& Savard, M.M. 2008. Multivariate statistical analysis of geochemical data as indicative of the hydrogeochemical evolution of groundwater in a sedimentary rock aquifer system. Journal of Hydrology, 353: 294-313. 
Das Brijraj, K., Kaur, P. 2007. Geochemistry of surface and subsurface waters of Rewalsar Lake, Mandi district, Himachal Pradesh: constraints on weathering and erosion. Journal Geological Society of India, 69(5): 1020-1030.

Domenico, P.A. 1972. Concepts and models in groundwater hydrology. McGraw-Hill, 405p. Elango, L., Kannan, R \& Senthil Kumar, M. 2003. Major ion chemistry and identification of hydrogeochemical processes of groundwater in a part of Kancheepuram district, Tamil Nadu, India. Journal of Environmental Geoscience, 10: 157-166.

Eskinder, Z. 2011. Assessment of the impact of industrial effluents on the quality of irrigation water and changes in soil characteristics: The case of Kombolcha town. Irrigation and Drainage, 60(5): 644-653.

Freeze, R.A \& Cherry, J.A. 1979. Groundwater. Prentice-Hall Inc., Vol. 7632, 604p.

Gastmans, D.; Chang, H.K.; Hutcheon, I. 2010. Groundwater geochemical evolution in the northern portion of the Guarani Aquifer System (Brazil) and its relationship to diagenetic features. Applied Geochemistry, 25: 16-33.

Gebremichael, A. 2011. Surface and groundwater potential assessments and environmental, socio-economical and legal considerations. Unpublished report.

GSE (Geological Survey of Ethiopia), 2010. Geology Geochemistry and Gravity Survey of the Dessie Area, GSE Memoir 28.

Gibbs, R.J. 1970. Mechanisms controlling world's water chemistry. Science, 170: 1088-1090. Hamere, Y \& Eyasu, E. 2017. Contamination of Rivers and Water Reservoirs in and Around Addis Ababa City and Actions to Combat It. Environ Pollut Climate Change, 1: 116.

Hem, J.D. (1989) Study and Interpretation of Chemical Characteristics of Natural Waters. $3^{\text {rd }}$ edition, US Geological Survey Water Supply Paper 2254.

Jalali, M. 2010. Groundwater geochemistry in the Alisadr, Hamadan, western Iran. Environmental Monitoring and Assessment, 166: 359-369.

Kolahchi, Z \& Jalali, M. 2006. Effect of water quality on the leaching of potassium from sandy soil. Journal of Arid Environment, 68: 624-639.

Kresic, N.N. 2007. Hydrogeology and groundwater Modeling. Taylor and Francis, 807p.

Kumar, M., Kumari, K., Singh, U.K \& Ramanathan, A.L. 2009. Hydrogeochemical processes in the groundwater environment of Muktsar, Punjab: conventional graphical and multivariate statistical approach. Environmental Geology, 57: 873-884. 
Lakshmanan, E., Kannan, R., and Senthil, M. 2003. Kumar Major Ion chemistry and identification of hydrogeochemical processes of ground water in a part of Kancheepuram district, Tamil Nadu, India. Environmental Geosciences, 10(4): 157-166.

Li, P., Qian, H., Howard, K.W.F \& Wu, J. 2015. Building a new and sustainable "Silk Road economic belt. Environ. Earth Sciences, 74: 7267-7270.

Li P., Wu, J \& Qian, H. 2016. Hydrochemical appraisal of groundwater quality for drinking and irrigation purposes and the major influencing factors: a case study in and around Hua County, China. Arabian J. Geoscience, 9:15.

Marco, B., Giacomo, C., Fabrizio, I., Piero, M., Francesco, M., Tsegaye, A \& Zoltan, P. 2005. Evolution of the Main Ethiopian Rift in the frame of Afar and Kenya rifts propagation. Tectonics, 24: 1007 (doi: 10.1029/2004TC001680).

Maya, A. L \& Loucks, M. D. 1995. Solute and isotopic geochemistry and groundwater flow in the Central Wasatch Range, Utah. Journal of Hydrology, 172: 31-59.

Mekonnen, G \& Yihenew, G. 2013. Pollution of Water, Soil and Vegetables: Challenges to Growing Cities of Bahir Dar and Kombolcha, Amhara Region, Ethiopia. Journal of Agricultural Science, 5(9): 22-28.

Mengesha, T., Tadiwos, C \& Werkneh, H. 1996. Explanation of the Geological Map of Ethiopia. Ethiopian Institute of Geological Survey, Addis Ababa, 3: 79.

Meybeck, M. 1987. Global Chemical Weathering of Surficial Rocks Estimated from River Dissolved. American Journal of Science, 287: 401-428.

Mohammed, A. 2015. Assessment of Heavy Metal Contamination Levels of the Vegetables Cultivated Along Two Tributaries of Borkena River at Kombolcha Town. MSc Thesis, Addis Ababa University (Unpubl.).

Moral, F., Cruz-Sanjulian, J.J \& Olias, M. 2008. Geochemical evolution of groundwater in the carbonate aquifers of Sierra de Segura (Betic Cordillera, southern Spain). Journal of Hydrology, 360(1-4): 281-296.

Nagaraju, A., Suresh, S., Killham, K \& Hudson, E.K. 2006. Hydrogeochemistry of Waters of Mangampeta Barite Mining Area, Cuddapah Basin, Andhra Pradesh, India. Turkish J. Engineering and Environmental Science, 30(4): 203-219.

Prasanna, M.V., Chidambaram, S., Thilagavathi, R., Thivya, C., Venkatramanan, S \& Murali Krishnan, N. 2019. A statistical approach to identify the temporal and spatial variations 
in the geochemical process of a coastal aquifer, South East Coast of India. In: GIS and Geostatistical Techniques for Groundwater, $1^{\text {st }}$ ed. 223-235.

Rajesh, R., Sreedhara, M.T.R \& Raghavan, B.R. 2002. The utility of multivariate statistical techniques in hydrogeochemical studies: an example from Karnataka, India. Water Research, 36: 2437-2442.

Schoeller, H. 1967. Geochemistry of groundwater. An international guide for research and practice. UNESCO, 15: 1-18.

Singh, C.K., Shashtri, S \& Mukherjee, S. 2011. Integrating multivariate statistical analysis with GIS for geochemical assessment of groundwater quality in Shiwaliks of Punjab, India. Environmental Earth Sciences, 62(7): 1387-1405.

Srinivasamoorthy, K., Chidambaram, S., Prasanna, M.V., Vasanthavihar, M., Peter, John \& Anandhan, P. 2008. Identification of major sources controlling groundwater chemistry from a hard rock terrain - a case study from Mettur taluk, Salem district, Tamil Nadu, India. Journal of Earth System Science, 117(1): 49-58.

Srivastava, S.K. and Ramanathan, A.L. 2008. Geochemical assessment of groundwater quality in vicinity of Bhalswa landfill, Delhi, India, using graphical and multivariate statistical methods. Environmental Geology, 53:1509-1528.

Tesfaye, D., Genet, Y., Abraham, M., Yibeltal, T., Yonas, T., Getachew, B., Mohammed, E \& Meran, W. 2010. Geology, geochemistry and gravity survey of the Dessie area. Report, $68 p$ (unpubl.).

Todd, D.K. 1980. Ground Water Hydrology. Wiley, New York.

Verma, D.K., Bhunia, G.S., Shit, P.K, Kumar, S., Mandal, J \& Padbhushan, R. 2016. Spatial variability of groundwater quality of Sabour block, Bhagalpur district (Bihar, India). Applied Water Science, (doi: 10.1007/s13201-016-0380-9).

Xiao, J., Jin, Z.D., Zhang, F \& Wang, J. 2012. Solute geochemistry and its sources of the groundwaters in the Qinghai Lake Catchment, NW China. J. Asian Ear. Sci., 52: 21-30.

Zaporozec, A. 1972. Graphical Interpretation of Water-Quality Data. Groundwater, 10: 32-43. 


\section{Appendix}

Appendix 1. Results of chemical analyses of the groundwater samples of the study area (Date of sampling: May 2017); Explanation: EC $(\mu \mathrm{S} / \mathrm{cm})$, concentrations $(\mathrm{mg} / \mathrm{l})$, temperature $\left({ }^{\circ} \mathrm{C}\right)$.

\begin{tabular}{|c|c|c|c|c|c|c|c|c|c|c|c|c|c|c|c|c|c|c|c|c|}
\hline No & $\begin{array}{c}\text { Sample } \\
\text { Id }\end{array}$ & $\mathbf{T}$ & pH & $\mathrm{Ca}^{2+}$ & $\mathbf{M g}^{2+}$ & $\mathbf{K}^{+}$ & $\mathrm{Na}^{+}$ & $\mathbf{N H}_{4}{ }^{+}$ & $\mathrm{Cl}^{-}$ & $\mathrm{SO}_{4}{ }^{2-}$ & $\mathrm{HCO}_{3}^{-}$ & $\mathrm{CO}_{3}{ }^{-}$ & $\mathrm{NO}_{3}{ }^{-}$ & $\mathrm{NO}_{2}^{-}$ & $\mathrm{PO}_{4}{ }^{3-}$ & $\mathbf{F}^{-}$ & TH & TDS & EC & $\begin{array}{c}\% \\
\text { Error }\end{array}$ \\
\hline 1 & BW-1 & 24.7 & 7.98 & 59 & 8 & 0.81 & 30 & 0.002 & 21.62 & 105 & 119.19 & 1.47 & 12.33 & 0.05 & 0.004 & 0.003 & 180.83 & 490.62 & 688 & -0.65 \\
\hline 2 & BW-2 & 24.6 & 8.01 & 49 & 6 & 0.73 & 36 & 0.003 & 23.83 & 103.37 & 104.22 & 1.46 & 13.42 & 0.04 & 0.002 & 0.005 & 147.5 & 418.59 & 587 & -2.9 \\
\hline 3 & BW-3 & 24.3 & 7.23 & 103 & 9 & 1.05 & 17 & 0.006 & 12.18 & 141.63 & 208.01 & 0.341 & 6.29 & 0.04 & 0.003 & 0.001 & 295 & 488.48 & 685 & -1.17 \\
\hline 4 & BGI-1 & 29.2 & 8.04 & 55 & 5 & 0.73 & 31 & 0.003 & 24.07 & 69.63 & 123.24 & 1.2 & 18.16 & 0.03 & 0.001 & 0.002 & 158.33 & 301.65 & 423 & 0.51 \\
\hline 5 & BGI-3 & 28.2 & 8.27 & 29 & 4 & 0.29 & 21 & 0.003 & 22.85 & 63.81 & 45.63 & 1.7 & 11.38 & 0.02 & 0.003 & 0.001 & 89.17 & 250.3 & 351 & -4.62 \\
\hline 6 & BGI-4 & 28.1 & 8.32 & 26 & 4 & 0.52 & 38 & 0.002 & 21.11 & 81.65 & 55.34 & 1.6 & 10.57 & 0.01 & 0.002 & 0.008 & 81.66 & 258.86 & 363 & -1.96 \\
\hline 7 & $\begin{array}{l}\text { ELF- } \\
\text { W1 }\end{array}$ & 25 & 7.51 & 175 & 10 & 1.07 & 42 & 0.001 & 38.67 & 171.89 & 413.45 & 0.659 & 13.28 & 0.05 & 0.006 & 0.007 & 479.16 & 657.77 & 921 & -1.11 \\
\hline 8 & SSH-W & 25.9 & 7.21 & 109 & 11 & 1.07 & 25 & 0.009 & 22.78 & 76 & 339.46 & 0.511 & 11.35 & 0.08 & 0.009 & 0.006 & 318.33 & 730.94 & 1025 & -3.36 \\
\hline 9 & SW-6 & 26.6 & 7.46 & 85 & 7 & 0.98 & 32 & 0.004 & 24.15 & 133.78 & 152.78 & 0.501 & 11.58 & 0.03 & 0.001 & 0.003 & 241.67 & 430 & 603 & 0.55 \\
\hline 10 & SW-8 & 25.4 & 8.06 & 77 & 6 & 0.51 & 31 & 0.002 & 23.52 & 65.52 & 185.19 & 1.33 & 16.82 & 0.02 & 0.002 & 0.001 & 217.69 & 358.69 & 503 & 2.94 \\
\hline 11 & $\begin{array}{l}\text { Tex- } \\
\text { W2 } \\
\end{array}$ & 28.1 & 6.93 & 85 & 4 & 0.91 & 41 & 0.002 & 31.53 & 82.67 & 201.12 & 0.084 & 13.15 & 0.02 & 0.006 & 0.001 & 229.16 & 448.55 & 629 & 2.1 \\
\hline 12 & $\begin{array}{l}\text { Tex- } \\
\text { W5 } \\
\end{array}$ & 27 & 7.78 & 42 & 5 & 0.91 & 30 & 0.002 & 25.14 & 31.58 & 136.78 & 0.792 & 11.53 & 0.04 & 0.002 & 0.003 & 125.83 & 360.83 & 506 & 0.23 \\
\hline 13 & $\begin{array}{l}\text { Tex- } \\
\text { W9 }\end{array}$ & 28.4 & 8.28 & 36 & 4 & 0.62 & 32 & 0.005 & 21.73 & 52.41 & 81.61 & 1.51 & 15.15 & 0.01 & 0.003 & 0.003 & 106.67 & 233.9 & 328 & 2.91 \\
\hline 14 & $\begin{array}{l}\text { Tex- } \\
\text { W10 } \\
\end{array}$ & 35.4 & 8.28 & 36 & 4 & 0.68 & 31 & 0.002 & 25.13 & 32.58 & 107.59 & 1.57 & 12.71 & 0.03 & 0.003 & 0.001 & 106.67 & 270.27 & 379 & 1.25 \\
\hline 15 & Tan-W & 24.5 & 7.72 & 168 & 10 & 1.09 & 32 & 0.006 & 26.17 & 154.92 & 364.33 & 1.46 & 10.68 & 0.08 & 0.007 & 0.009 & 461.67 & 759.46 & 1065 & 2.33 \\
\hline 16 & $\begin{array}{l}\text { KCTW- } \\
\text { 2R }\end{array}$ & 27.5 & 7.95 & 76 & 6 & 0.69 & 25 & 0.004 & 19.87 & 72.74 & 159.97 & 1.14 & 12.93 & 0.04 & 0.003 & 0.001 & 215 & 343.72 & 482 & 4.39 \\
\hline 17 & KO-W2 & 27.9 & 7.59 & 106 & 8 & 1.01 & 52 & 0.006 & 25.23 & 186.72 & 228.12 & 0.629 & 11.32 & 0.07 & 0.007 & 0.007 & 298.33 & 733.08 & 1028 & -1.77 \\
\hline \multirow[t]{5}{*}{18} & YM-2 & 28.1 & 7.94 & 38 & 4 & 0.93 & 29 & 0.001 & 22.11 & 32.54 & 129.79 & 0.986 & 9.15 & 0.03 & 0.002 & 0.004 & 111.66 & 298.08 & 418 & -1.34 \\
\hline & Min & 24.3 & 6.93 & 26 & 4 & 0.29 & 17 & 0.001 & 12.18 & 31.58 & 45.63 & 0.08 & 6.29 & 0.01 & 0.001 & 0.001 & 81.66 & 233.9 & 328 & \\
\hline & Max & 35.4 & 8.32 & 175 & 11 & 1.09 & 52 & 0.009 & 38.67 & 186.72 & 413.45 & 1.7 & 18.16 & 0.08 & 0.009 & 0.009 & 479.16 & 759.46 & 1065 & \\
\hline & $\begin{array}{l}\text { Sta. } \\
\text { Dev }\end{array}$ & 2.61 & 0.41 & 44.13 & 2.4 & 0.23 & 8.03 & 0.002 & 5.22 & 47.85 & 103.98 & 0.5 & 2.68 & 0.02 & 0.002 & 0.003 & 118.87 & 176.01 & 247 & \\
\hline & Mean & 27.16 & 7.81 & 75.22 & 6.39 & 0.81 & 31.9 & 0.004 & 23.98 & 92.14 & 175.32 & 1.05 & 12.32 & 0.04 & 0.004 & 0.004 & 214.69 & 435.21 & 610 & \\
\hline
\end{tabular}


Appendix 2. Results of chemical analyses of the groundwater samples of the study area (Date of sampling: Nov 2017); Explanation: EC $(\mu \mathrm{S} / \mathrm{cm})$, concentrations $(\mathrm{mg} / \mathrm{l})$, temperature $\left({ }^{\circ} \mathrm{C}\right)$.

\begin{tabular}{|c|c|c|c|c|c|c|c|c|c|c|c|c|c|c|c|c|c|c|c|c|}
\hline No & Sample Id & $\mathbf{T}$ & $\mathbf{p H}$ & $\mathrm{Ca}^{2+}$ & $\mathbf{M g}^{2+}$ & $\mathbf{K}^{+}$ & $\mathbf{N a}^{+}$ & $\mathrm{NH}_{4}{ }^{+}$ & $\mathrm{Cl}^{-}$ & $\mathrm{SO}_{4}^{2-}$ & $\mathrm{HCO}_{3}^{-}$ & $\mathrm{CO}_{3}^{-}$ & $\mathrm{NO}_{3}^{-}$ & $\mathrm{NO}_{2}^{-}$ & $\mathrm{PO}_{4}{ }^{3-}$ & $\mathbf{F}^{-}$ & TH & TDS & EC & $\begin{array}{c}\% \\
\text { Error }\end{array}$ \\
\hline 1 & BW-1 & 22.8 & 8.07 & 75 & 19 & 0.93 & 16 & 0.002 & 5.12 & 105.11 & 194.13 & 0.085 & 4.23 & 0.04 & 0.002 & 0.002 & 293.9 & 340.2 & 477 & 3.85 \\
\hline 2 & BW-2 & 23 & 7.66 & 65 & 16 & 0.98 & 12 & 0.006 & 8.77 & 71.89 & 213.5 & 0.289 & 4.08 & 0.06 & 0.003 & 0.003 & 229.3 & 413.6 & 580 & -1.97 \\
\hline 3 & BW-3 & 22.8 & 7.59 & 96 & 5 & 1.02 & 11 & 0.005 & 6.11 & 86.22 & 250.1 & 0.055 & 3.25 & 0.03 & 0.006 & 0.003 & 260.8 & 489.9 & 687 & -3.42 \\
\hline 4 & BGI-1 & 27.5 & 7.61 & 45 & 7 & 0.98 & 5 & 0.002 & 5.01 & 49 & 123.61 & 0.051 & 1.51 & 0.05 & 0.001 & 0.001 & 135 & 288.5 & 404 & -1.95 \\
\hline 5 & BGI-3 & 26.6 & 7.56 & 53 & 5 & 0.69 & 7 & 0.003 & 4.12 & 49.66 & 152.3 & 0.071 & 1.02 & 0.02 & 0.001 & 0.001 & 153.3 & 284.5 & 349 & -4.1 \\
\hline 6 & BGI-4 & 26.4 & 7.77 & 48 & 4 & 0.61 & 8 & 0.002 & 5.72 & 36.15 & 115.9 & 0.021 & 2.01 & 0.01 & 0.001 & 0.001 & 136.7 & 260.3 & 365 & 4.14 \\
\hline 7 & ELF-W1 & 23.2 & 7.53 & 102 & 12 & 1.02 & 32 & 0.006 & 25.67 & 98.62 & 294.1 & 0.084 & 9.13 & 0.07 & 0.005 & 0.003 & 305 & 634.7 & 890 & -1.6 \\
\hline 8 & SSH-W & 24.2 & 8.11 & 44 & 7 & 1.03 & 5.8 & 0.002 & 6.11 & 50.13 & 123.59 & 0.045 & 2.01 & 0.06 & 0.003 & 0.001 & 118 & 307.4 & 431 & -3.51 \\
\hline 9 & SW-6 & 24.9 & 8.08 & 44 & 8 & 1.03 & 6.2 & 0.002 & 5.34 & 51 & 124.13 & 0.047 & 2.81 & 0.07 & 0.002 & 0.002 & 122 & 309.5 & 434 & -2.18 \\
\hline 10 & SW-8 & 24.8 & 7.69 & 62 & 8 & 0.83 & 18 & 0.003 & 12.15 & 51.79 & 186.69 & 0.077 & 6.42 & 0.04 & 0.003 & 0.004 & 188.3 & 349.4 & 490 & -0.28 \\
\hline 11 & Tex-W2 & 25.6 & 7.56 & 88 & 12 & 0.99 & 22 & 0.005 & 16.24 & 63.98 & 298.54 & 0.067 & 8.12 & 0.06 & 0.003 & 0.002 & 263.3 & 499.9 & 701 & -3.39 \\
\hline 12 & Tex-W5 & 25.3 & 7.7 & 52 & 11 & 1.02 & 8 & 0.003 & 3.15 & 112.78 & 101.3 & 0.027 & 2.31 & 0.04 & 0.004 & 0.002 & 175.8 & 343.7 & 482 & -3.2 \\
\hline 13 & Tex-W9 & 27.6 & 7.68 & 44 & 4.3 & 0.97 & 5.8 & 0.002 & 2.41 & 47 & 118.92 & 0.056 & 1.25 & 0.04 & 0.002 & 0.002 & 125 & 233.2 & 327 & -3.2 \\
\hline 14 & Tex-W10 & 26.5 & 8.01 & 42 & 4 & 0.54 & 12 & 0.001 & 5.67 & 52.18 & 106.4 & 0.038 & 3.15 & 0.02 & 0.001 & 0.001 & 121.7 & 244.6 & 343 & -1.29 \\
\hline 15 & Tan-W & 23.4 & 6.99 & 178 & 11 & 1.22 & 33.1 & 0.005 & 39.61 & 145.61 & 359.23 & 0.139 & 15.62 & 0.06 & 0.04 & 0.07 & 521 & 836.6 & 1233 & 4.53 \\
\hline 16 & KCTW-2R & 25.5 & 7.9 & 41 & 5 & 0.98 & 5.2 & 0.001 & 5.36 & 47 & 111.87 & 0.039 & 1.98 & 0.03 & 0.001 & 0.001 & 116 & 305.9 & 429 & -4.98 \\
\hline 17 & KO-W2 & 25.4 & 7.39 & 72 & 13 & 0.73 & 11 & 0.005 & 9.61 & 65.12 & 225.7 & 0.071 & 5.05 & 0.04 & 0.002 & 0.003 & 234.2 & 376.5 & 528 & -2.3 \\
\hline \multirow[t]{5}{*}{18} & YM-2 & 26.2 & 7.39 & 121 & 25 & 1.57 & 32 & 0.009 & 25.28 & 105.71 & 377.09 & 0.142 & 10.37 & 0.09 & 0.005 & 0.008 & 406.7 & 763.3 & 1069 & 1.44 \\
\hline & Min & 22.8 & 6.99 & 41 & 4 & 0.54 & 5 & 0.001 & 2.41 & 36.15 & 101.3 & 0.021 & 1.02 & 0.01 & 0.001 & 0.001 & 116 & 233.2 & 327 & \\
\hline & Max & 27.6 & 8.11 & 178 & 25 & 1.57 & 33.1 & 0.009 & 39.61 & 145.61 & 377.09 & 0.289 & 15.62 & 0.09 & 0.04 & 0.07 & 521 & 836.6 & 1233 & \\
\hline & Sta. Dev & 1.57 & 0.28 & 35.79 & 5.77 & 0.23 & 9.69 & 0.002 & 9.98 & 30.31 & 89.98 & 0.06 & 3.89 & 0.02 & 0.01 & 0.02 & 111.9 & 176.3 & 258.17 & \\
\hline & Mean & 25.09 & 7.68 & 70.67 & 9.79 & 0.95 & 13.9 & 0.004 & 10.64 & 71.61 & 193.17 & 0.08 & 4.68 & 0.05 & 0.005 & 0.01 & 217 & 404.5 & 567.72 & \\
\hline
\end{tabular}

